\title{
Inleiding
}

\section{De internationalisering van de nationale geschiedenis en de verzuiling}

\author{
Henk te Velde
}

\begin{abstract}
Introduction. The Internationalization of the National History and the Pillarization
Efforts to approach Dutch political history from an international perspective have been going on for a long time. This has worked rather well for the early modern period, before the national state existed in a modern form. Nevertheless, applying this to the last few centuries remains a challenge. This is because this period was dominated by the national state and historiography was focussed on the state from the very beginning. Eliminating the national aspect from historiography altogether would not be a desirable course of action. However, it is necessary to be aware of the effects it has, and each generation has its own way of doing this. Nowadays, international comparisons and the history of transfers offer new opportunities. It is against this backdrop that the introduction explains how pillarization expanded to become the Dutch Sonderweg and how a new approach towards political history can compensate for the disadvantages of this perspective.
\end{abstract}

'Vaderlandse geschiedenis in hedendaags perspectief' is een titel die op veel momenten gebruikt had kunnen worden. Het was in ieder geval de titel van de rede waarmee J.C. Boogman in 1959 in Utrecht aantrad als hoogleraar. De Europese natie-staat had aan macht en prestige ingeboet en het nationalisme van negentiende-eeuwse historici was, in de woorden van Boogman, 'ons in veel opzichten volslagen vreemd geworden'. ${ }^{1}$ Hij bepleitte dan ook aansluiting bij internationale vernieuwing in de geschiedwetenschap door de school rond het Franse tijdschrift Annales en door het prosopografische onderzoek van de Britse groep rond de politiek historicus Lewis Namier. Vooral teleologie en finalisme moesten het bij Boogman ontgelden. De moderne historicus moest zich er verre van houden.

In 1983 nam Piet Blaas Boogmans rede als beginpunt voor een beschouwing over de Nederlandse geschiedschrijving na 1945. Als een echo van Boogman zei hij, bijna vijfentwintig jaar later, dat het 'verleden van de Opstand, van de Republiek en het $19^{\mathrm{e}}$-eeuwse Koninkrijk [...] ons in vele opzichten vreemd geworden' was. Hij signaleerde voor de geschiedschrijving over de zeventiende eeuw inmiddels ook een 'denationaliseringstendens', niet zoals we nu wellicht zouden verwachten in de zin van internationale vergelijking maar vooral door aandacht voor kleinere eenheden in plaats van de natie als eenheid van analyse. Voor de historiografie van de negentiende eeuw nam hij zoiets nog niet waar, daar constateerde hij slechts een langzame en

1 J.C. Boogman, Vaderlandse geschiedenis in hedendaags perspectief. Rede (Groningen 1959) 6 en passim. 
moeizame vernieuwing. ${ }^{2}$

Boogman had al een begin gemaakt met de bestudering van het negentiende-eeuwse nationalisme, maar internationaal zou vooral in de jaren tachtig de studie van dat verschijnsel nieuwe wegen inslaan aan de hand van auteurs als Ernest Gellner, Benedict Anderson en Eric Hobsbawm en het Franse onderzoek naar de lieux-de-mémoire van Pierre Nora, dat wat later in Nederland bekend zou worden. Dit was niet het einde van nationale politieke geschiedenis. Het was eerder een soort nationale geschiedenis van de tweede orde, kritisch en reflexief maar nog steeds met het uitgangspunt in de natie. Inmiddels is Boogmans verhaal vijftig jaar oud, maar teleologie bestrijden we nog steeds en we schrijven ook nog steeds nationale geschiedenis. Dat is ook niet vreemd. Nationale staten beheersen ondanks alle veranderingen nog steeds ons wereldbeeld en ze hebben de twintigste en een belangrijk deel van de negentiende eeuw gedomineerd. Ook in de huidige Europese Unie domineert het nationale perspectief zozeer, dat er nog steeds amper een Europese publieke opinie bestaat en dat de bevolking van de lidstaten zich politiek nog steeds vooral in nationale kaders voorstelt en 'Brussel' negeert of er zich van afkeert. In hoeverre het nationale perspectief ook vóór de negentiende eeuw bruikbaar is, is omstreden, al is het in de geschiedschrijving daarover in het verleden lang dominant geweest. Het is daar in ieder geval een stuk minder vanzelfsprekend en dit is dan ook een belangrijke reden dat de geschiedschrijving van de vroegmoderne tijd zich gemakkelijker aan een exclusief nationale benadering heeft kunnen ontworstelen dan die van de periode na 1800 . Het blijkt al uit de opmerking van Blaas hierboven en op een andere manier uit de bijdragen van Judith Pollmann en Jeroen Duindam aan dit nummer.

Hoe dan ook hebben historici een eigenaardige relatie met de natie. Dat is al vanaf het begin zo. Een voorkeur voor het nationale perspectief is eigen aan het vak sinds de ontwikkeling ervan in de negentiende eeuw. Nationale politieke geschiedenis was de kern van de discipline en dat was niet alleen een wetenschappelijk uitgangspunt, maar ook een maatschappelijke opdracht. Niet in de zin van een onkritische verheerlijking van de eigen natie, maar toch wel in de betekenis van onderstreping van nationale eendracht en kracht, zoals Piet Blaas in een bekend artikel uit de jaren 1980 heeft laten zien voor de Nederlandse historici Robert Fruin en P.J. Blok. ${ }^{3}$ De negentiende eeuw is lang geleden en de historische wetenschap zit nu geheel anders in elkaar. Toch blijft juist bij het zo nauw met de wording van het vak verbonden onderwerp van de nationale politieke geschiedenis een vorm van navelstaarderij dreigen. Sinds de tijd van Fruin en Blok zijn er natuurlijk oplossingen aangedragen voor dat probleem. Onder meer door te kiezen voor andere subdisciplines zoals de sociale en economische geschiedenis en cultuurgeschiedenis die minder aan nationale kaders zijn verbonden en als het ware minder erfelijk belast zijn.

2 P.B.M. Blaas, 'Nederlandse geschiedschrijving na 1945', in: W.W. Mijnhardt (ed.), Kantelend geschiedbeeld. Nederlandse historiografie sinds 1945 (Utrecht en Antwerpen 1983) 9-47.

3 P.B.M. Blaas, 'De prikkelbaarheid van een kleine natie met een groot verleden: Fruins en Bloks nationale geschiedschrijving' (1982), in: idem, Geschiedenis en nostalgie. De historiografie van een kleine natie met een groot verleden (Hilversum 2000) 15-41. 
Het neemt allemaal de legitimiteit van de nationale politieke geschiedenis niet weg. De vernieuwing van de politieke geschiedenis van de laatste decennia heeft die door verbredingen en door een verbinding met andere subdisciplines zelfs versterkt. De ervaring van de afgelopen eeuw heeft daarbij geleerd hoe lastig het is een nationale bias te vermijden. Het is ook niet verstandig te streven naar een definitieve uitbanning van alle nationale beperkingen uit de geschiedwetenschap. Dat zou al snel een steriele speurtocht worden naar een standplaatsloze geschiedwetenschap. Beter is het periodiek onderhoud te plegen. Laten we liever van tijd tot tijd de balans opmaken, zoals Boogman dat aan het einde van de jaren vijftig deed, zoals dat in en door het nationalismeonderzoek in de jaren tachtig is gebeurd en zoals we dat op dit moment kunnen doen door de discussie aan te gaan over de betekenis voor de nationale geschiedenis van vergelijking en overname van buitenlandse voorbeelden. Dat is zeker voor de traditioneel nogal tot streng empirisme geneigde politieke geschiedenis al heel wat.

Dit is de bescheiden opdracht voor dit themanummer, maar die is al moeilijk genoeg. De negentiende-eeuwse historici hielden zich veel meer met de Opstand en de Republiek dan met hun eigen tijd bezig. Zo werd het nationale perspectief aanvankelijk juist nadrukkelijk op de vroegmoderne tijd gericht en die neemt dus in een evaluatie van dat nationale perspectief vanzelfsprekend een belangrijke positie in. Inmiddels is wel duidelijk hoezeer een concentratie op het nationale element de werkelijkheid van de vroegmoderne tijd geweld aandoet; dat is geen nieuw inzicht meer. Al lang is het nationale perspectief op die periode sterk gerelativeerd, ook al doordat de negentiendeeeuwse geschiedschrijving juist op dat punt evident eenzijdig was. Rekening houden met de internationale context ligt ook voor de hand door de grote belangstelling die buitenlandse historici, van Geoffrey Parker tot Jonathan Israel, aan de Republiek hebben geschonken. Zelfs als die buitenlanders vooral in het eigen karakter van het Nederlandse volk geïnteresseerd waren, zoals Simon Schama in zijn Embarrassment of Riches, openden ze de laatste decennia de geschiedenis van de Republiek voor een internationaal publiek waardoor internationale uitwisseling gestimuleerd werd. Dit is duidelijk anders dan toen John Lothrop Motley met The Rise of the Dutch Republic in de negentiende eeuw vooral de nationale trots in Nederland stimuleerde.

Lastiger is het nog steeds voor de tijd daarna. Aangezien daar nog meer werk te doen is en de opmars van de nationale staat het nationale kader zelf in de negentiende en twintigste eeuw dwingender maakte, zal ik me in deze inleiding op die laatste periode concentreren. Die is ook het beste uitgangspunt voor dit themanummer zoals ik aan de hand van de verzuiling zal betogen. De evaluatie beperkt zich daarnaast tot het domein van een breed opgevatte politieke geschiedenis. Vooral in de politieke geschiedenis van de laatste eeuwen is immers het nationale perspectief altijd overheersend geweest en domineert dat ook vandaag nog het meeste. Zo is enerzijds de concentratie op politiek en anderzijds het onderscheid tussen de vroegmoderne en de moderne periode verklaard. Verder is duidelijk dat de discussie over de internationalisering van de nationale geschiedenis voor iedere periode eigen vormen aan heeft genomen, wat aan dit themanummer een kaleidoscopisch karakter geeft. Het 
duidelijkste blijkt de noodzaak van een periodegebonden aanpak wellicht uit het artikel van Annie Jourdan over de periode rond 1800. Voor die periode is de buitenlandse invloed al lang duidelijk. Maar de interpretatie daarvan werd lange tijd veelal getekend door ofwel een nadruk op de imitatie van Frankrijk die de revolutionaire periode beheerst zou hebben, ofwel juist van de weeromstuit een beklemtoning van het eigen, Nederlandse karakter van de vernieuwingen uit die tijd. Jourdan betoogt dat het vruchtbaarder is de Franse en andere buitenlandse invloed te erkennen, maar dan ook te laten zien dat die aan de specifieke eisen van de Nederlandse situatie werd aangepast, en dat Nederland niet alleen ontvanger maar ook zender van voorbeelden was. Niet toevallig publiceerde zij zojuist een studie over de Bataafse revolutie 'entre la France et l'Amérique' en schreef zij als productieve auteur al eerder een boek over de 'mythe' van de Franse Revolutie als 'exception française'. Net zo min als Nederland ontwikkelde Frankrijk zich in een vacuüm of waren de ontwikkelingen in dat land geheel uniek. ${ }^{4}$

In de geschiedschrijving van de negentiende-eeuwse en twintigste-eeuwse Nederlandse politiek heeft zich de afgelopen jaren een zekere verschuiving voorgedaan. Was die nog tot in de jaren negentig vooral erop gericht het eigene van de nationale geschiedenis te ontdekken, en bestudeerde men nationale politiek omdat die nationaal was, nu lijkt er een tendens te zijn om nationale politiek vooral te bestuderen omdat die politiek is. De ontwikkeling is terug te zien in allerlei recente onderzoeksprogramma's en in initiatieven tot internationale vergelijking en onderzoek van buitenlandse inspiratie en voorbeelden. Het in de jaren tachtig gestarte Amsterdamse onderzoeksprogramma over verzuiling in Nederland van Hans Blom en anderen was gericht op een Nederlands verschijnsel waarvan de lokale varianten werden onderzocht, het NWO-programma over politiek in Nederland 'De Natiestaat' dat op initiatief van Piet de Rooy en weer Hans Blom in de jaren negentig begon, was op onderdelen al wel vergelijkend, maar dat was voor geen van de onderzoeken de hoofdzaak. Het Groningse NWO-pionierprogramma over politieke cultuur van weer een aantal jaren later bestond voor een gedeelte uit internationale onderdelen, het programma uit de Vernieuwingsimpuls van Ido de Haan over politiek en regime changes en de historische onderdelen uit het NWOprogramma 'Omstreden Democratie' zijn expliciet vergelijkend.

Dit zal allemaal net zo min een definitief afscheid van nationale beperkingen betekenen als eerdere vernieuwingspogingen, maar het is nuttig de recente verandering te markeren en de balans van de nationale geschiedenis opnieuw op te maken. Dit nummer heeft daarmee niet de pretentie nieuwe wegen in te slaan, maar aan de hand van historiografie en nieuwe voorbeelden duidelijk te maken welke wegen historici van de politiek in feite al bewandelen. Het uitgangspunt daarbij is dus dat de kwestie van de internationalisering het meeste speelt in de politieke geschiedenis en daarbinnen dan weer het meeste

4 Annie Jourdan, La Révolution, une exception française? (Parijs 2004), onder meer 365-374 en 17: 'échanger la rhétorique nationaliste de l'unicité contre une logique universaliste des spécificités'; Idem, La Révolution batave entre la France et l'Amérique (1795-1806) (Rennes 2008). 
in de moderne tijd. Heel duidelijk komt het naar voren in de geschiedenis van de verzuiling die daarom in deze inleiding centraal staat. Dat thema is niet zomaar een illustrerend voorbeeld, maar wellicht de meest pregnante casus van een nog voor tot voor kort dominante interesse in het specifiek Nederlandse van een politiek-sociaal verschijnsel en een recente verandering naar een meer (inter)nationale oriëntatie van de politieke geschiedenis. Het gaat daarom vooraf aan de chronologische orde die de rest van het nummer kenmerkt.

\section{De verzuiling als Nederlandse Sonderweg}

Van de jaren vijftig tot zeker in de jaren tachtig van de twintigste eeuw werd de beschouwing van de nationale politieke geschiedenis niet alleen in Nederland maar ook in veel andere landen bepaald door de overtuiging dat het eigen land een speciale weg had gekozen naar de moderne wereld van de hedendaagse democratie. Deze gedachte kon het uitgangspunt zijn voor concreet onderzoek, maar was vooral invloedrijk als alom aanwezige achtergrondgedachte. Het beroemdste voorbeeld daarvan is de Duitse Sonderweg. ${ }^{5}$ De Duitse misère van de twintigste eeuw zou veroorzaakt zijn door de eigenaardige ontwikkeling van de Duitse geschiedenis. $\mathrm{Nu}$ is het onomstreden dat er specifiek Duitse oorzaken voor de Duitse catastrofe waren, maar de gedachte van de Sonderweg suggereert ook dat de Duitse geschiedenis een specifieke afwijking inhoudt van een bepaalde normale weg. Al in de jaren tachtig betoogden historici dat die normale weg impliciet dan in feite de Britse zou moeten zijn (van geleidelijke ontwikkeling van een parlementaire democratie). ${ }^{6}$ Als die impliciete aannames geëxpliciteerd werden, bleek het allemaal niet zo vanzelfsprekend te zijn als het op het eerste gezicht leek. De Britten hechtten zelf immers weer juist aan een 'British exceptionalism' dat zou afwijken van een verondersteld continentaal patroon. Als dit continentale patroon dan in feite het Franse zou zijn, stuitte het ook weer op problemen, aangezien de Fransen nog luider dan anderen een eigen 'exception française' opeisten die nog weer uitzonderlijker zou zijn dan andere uitzonderingen omdat die claimde van universele betekenis te zijn (door de internationale werking van de Revolutie). Net zo min als de Britse ontwikkeling, kon de Franse dus als maatstaf dienen om een Sonderweg tegen af te zetten. Datzelfde gold ook voor de Amerikaanse ontwikkeling, want ook Amerikanen beschouwden zich nu juist weer als 'exceptional', wat toen vooral niet-Europees betekende.

5 Een puntige terugblik op de enorme literatuur is James J. Sheehan, 'Paradigm Lost? The "Sonderweg" Revisited', in: Gunilla Budde, Sebastian Conrad en Oliver Janz (eds.), Transnationale Geschichte. Themen, Tendenzen und Theorien (Göttingen 2006) 150-160; zie ook Jürgen Kocka, 'Asymmetrical Historical Comparison. The Case of the German Sonderweg', History and Theory (1999) 40-50 (een van de samenvattende én problematiserende artikelen die Kocka over de materie schreef).

6 David Blackbourn en Geoff Eley, The Peculiarities of German History (New York 1984).

7 Uitgebreider, met literatuurverwijzingen, in Henk te Velde, 'The Dilemma of National 
Deze opeenstapeling van uitzonderingen heeft iets eigenaardigs. Nationale ontwikkelingen hebben allemaal iets eigens, maar het is duidelijk dat daar wel erg veel nadruk op werd gelegd. Of iets uitzonderlijk is, kan slechts worden vastgesteld door vergelijking. De vergelijking bleef in dit verband meestal impliciet. Wel veronderstelden en bevestigden de verschillende exceptionalismen elkaar. Dat is ook zichtbaar in het Nederlandse geval. De verschillende Sonderwege zeiden allemaal iets over de modernisering en de ontwikkeling van democratie in de betrokken landen; ze vormden in wezen alle een commentaar op of een verhaal over de specifieke manier waarop een bepaald land hiermee was omgegaan. Het Nederlandse equivalent hiervan is het verhaal over de verzuiling geweest. Dat het hier ging om een (eigen) variant van een internationaal patroon werd in de tijd dat dit verhaal zich ontwikkelde niet echt herkend, en het is tot dusver ook niet systematisch op deze manier bekeken. Maar meer dan de Gouden Eeuw of de Opstand, is de verzuiling vanaf de jaren vijftig in feite gepresenteerd als de Nederlandse Sonderweg, de specifieke vorm van de modernisering en de weg naar de moderne samenleving die Nederland zou hebben gekozen. Deze weg werd dan overigens wel vaak nogal kritisch benaderd.

Het begrip verzuiling was al iets ouder, maar het werd als wetenschappelijk concept voor het eerst vormgegeven in de jaren vijftig. Toen al riep de historicus Ivo Schöffer op aandacht te besteden aan wat hij 'het specifiek Nederlandse karakter van de verzuiling' noemde, waarmee hij vooral de gemeenschappelijke koepel boven de zuilen bedoelde. ${ }^{8}$ Nog in 1990 klaagde een Belgische onderzoeker dat het 'Nederlandse particularisme' in het onderzoek van dit verschijnsel zo ver ging dat het Belgische verzuilingsonderzoek geheel over het hoofd werd gezien. ${ }^{9}$ Als dit al het geval was, dan was dit echter niet het gevolg van een exclusief Nederlandse orientatie van het verzuilingsonderzoek. Dat nam zoals bekend pas een hoge vlucht in de jaren zestig door het onderzoek van politicologen als Hans Daalder en Arend Lijphart. Deze reageerden nu juist op internationaal democratieonderzoek. De dominantie daarin van de Angelsaksische tweepartijenpoliticologie die gescheiden maatschappelijke groepen in de vorm van zuilen vooral als gevaar voor democratie en stabiliteit beschouwde, riep om een reactie, zoals Daalder in een terugblik opmerkte. 'You know, your country theoretically cannot exist', kreeg hij te horen. ${ }^{10}$

Het is dus niet toevallig dat in enkele jaren tijds niet alleen in Nederland maar ook in andere kleine landen met een vergelijkbare structuur zoals België,

History', in: Knowledge in Ferment. Dilemmas in Science, Scholarship and Society (Leiden 2007) $227-241$.

8 I. Schöffer, 'Verzuiling een specifiek Nederlands probleem', Sociologische Gids (1956) 121-127.

9 Staf Hellemans, Strijd om de moderniteit. Sociale bewegingen en verzuiling in Europa sinds 1800 (Leuven 1990) 11.

10 H. Daalder, 'The Consociational Democracy Theme' (1974), in: idem, Politiek en Historie. Opstellen over Nederlandse politiek en vergelijkende politieke wetenschap, J.Th.J. van den Berg en B.A.G.M. Tromp (eds.) (Amsterdam 1990) 364. 
Zwitserland en Oostenrijk boeken verschenen met een vergelijkbare strekking. ${ }^{11}$ Wat gesimplificeerd ${ }^{12}$ zouden die voorgesteld kunnen worden als een antwoord op vooral Amerikaans internationaal vergelijkend onderzoek naar politieke systemen. Het bekendste voorbeeld daarvan is een artikel van de Amerikaanse politicoloog Gabriel Almond uit de jaren vijftig. Dat zet de prachtige Britse en Amerikaanse politieke orde af tegen de onprettige resultaten van anders georiënteerde systemen. Almond meende dat de democratie in het Duitse, Italiaanse en ook Franse politieke model veel meer gevaar liep dan in het Angelsaksische, onder meer doordat maatschappelijke versplintering in allerlei 'subculturen' redelijke compromissen in de weg stond. De boeken over de kleine landen wilden daarentegen juist tonen dat de democratie even goed kon werken in landen met een reeks subculturen, ja, die subculturen konden onder bepaalde omstandigheden de democratie zelfs schragen.

In dit debat ging het om internationale vergelijking, maar het oorspronkelijke artikel van Almond zelf was wel erg nadrukkelijk vanuit Amerikaans perspectief geschreven. Dat blijkt wel uit enkele inleidende zinnen: 'as our [Amerikaanse] international interests have expanded and become more urgent, our requirements in knowledge have become more exacting', zo schreef hij, en hij vervolgde met enige neerbuigendheid: 'We can no longer view political crises in France with detached curiosity or view countries such as Indo-China and Indonesia as interesting political pathologies'. ${ }^{13}$ Zulke beschouwingen namen de Verenigde Staten zozeer als maatstaf, dat het niet vreemd is dat de reacties ook weer een nationale kleur kregen. Zoals eerder de Fransen en de Britten hadden nu de Amerikanen de neiging hun vorm van politiek als universele maatstaf voor te stellen en in ieder geval van universele betekenis te achten. Achteraf kan worden vastgesteld dat zo vooral onderzoek naar de nationale eigenheid van andere landen werd gestimuleerd. Onder anderen de bekende politicoloog Arend Lijphart heeft er zijn wetenschappelijke carrière op gebouwd - die overigens grotendeels, niet toevallig, Amerikaans is geweest.

11 L. Huyse, Passiviteit, pacificatie en verzuiling in de Belgische politiek. Een sociologische studie (Antwerpen 1970); G. Lehmbruch, A Non-Competitive Pattern of Conflict Management in Liberal Democracies. The Cases of Switzerland, Austria and Lebanon (Brussel 1967); J. Steiner, Gewaltlose Politik und Kulturelle Vielfalt. Hypothesen entwickelt am Beispiel der Schweiz (Bern 1970).

12 Een breed overzicht van de meer algemene vergelijkende politicologische discussie waarin dit alles thuis hoort in Hans Daalder, 'On the Origins of the Consociational Democracy Model', Acta Politica (1984) 97-116. Arend Lijphart, 'Typologies of Democratic Systems', Comparative Political Studies 1 (1968) 3-44, plaatst het onderzoek naar verzuiling en vergelijkbare systemen in Nederland en andere kleine landen in een theoretisch perspectief waarin ook weer het hierna te citeren artikel van Almond prominent figureert.

13 Gabriel A. Almond, 'Comparative Political Systems', The Journal of Politics 18 (1956) 391409; aldaar 391. In de praktijk was natuurlijk het wat latere bekende boek Gabriel A. Almond en Sidney Verba, The Civic Culture. Political Attitudes and Democracy in Five Nations (Princeton 1963) de centrale tekst in het debat; ook in dit boek is het Amerikaanse (en Britse) model in feite maatgevend. 
Hoewel door de vrijwel gelijktijdige verschijning van een aantal met name politicologische studies al snel duidelijk kon zijn dat aspecten van verzuiling dus op zijn minst in een aantal kleine landen voorkwamen, concentreerde de Nederlandse discussie onder historici maar ook politicologen zich op nationale eigenaardigheden. Zoals gezegd onderzocht de historicus Schöffer vooral het eigen Nederlandse karakter van de verzuiling en in dezelfde jaren vijftig noemde de historicus Frits de Jong de verzuiling een 'vaderlands fenomeen'. De politicoloog Lijphart was in de jaren zestig met name geïnteresseerd in verzuiling en de bijbehorende pacificatiepolitiek als iets dat in Nederland sterker aanwezig was dan elders. ${ }^{14}$ En nog in de jaren tachtig beschreef de politicoloog Siep Stuurman, die het verder geheel oneens was met Lijphart, de verzuiling 'als specifiek Nederlands verschijnsel'. Hij was verre van een nationalist en keerde zich ook expliciteit tegen het finalisme in andere verklaringen van de verzuiling. Ook deed hij aan internationale vergelijking en besteedde hij aandacht aan buitenlandse invloeden, maar al deze energie richtte zich op het beklemtonen van de uitzonderlijke Nederlandse situatie. Ongeveer de eerste zin van zijn boek was: 'Met een verwijzing naar de verzuiling duidt men gewoonlijk het eigene en kenmerkende van de Nederlandse politieke geschiedenis aan. ${ }^{, 15}$ Enkele jaren later namen de historici Karel Davids, Jan Lucassen en Jan Luiten van Zanden de verzuiling op in hun voorstel voor een onderzoek naar de Nederlandse geschiedenis als 'afwijking van het algemeen menselijk patroon'. ${ }^{16}$

\section{Verzuiling en vergelijking}

De verzuiling als afwijking van het algemeen menselijk patroon, het zou een mooie titel zijn voor een ironische beschouwing. Dat is hier in het geheel niet de bedoeling. Het gaat er eerder om te laten zien dat wat enerzijds navelstaarderij kan lijken, anderzijds een belangrijke bijdrage aan de wetenschap kan zijn. Davids, Lucassen en Van Zanden hebben hun programma deels uitgevoerd, met een mooie vergelijkende studie over de Nederlandse Republiek. ${ }^{17}$ Vergelijking diende hier om het specifieke van Nederland aan te tonen. Dit is de vorm van vergelijking die ook elders in nationale politieke geschiedenis het meeste is gebruikt. Soms wordt dan verwezen naar John Stuart Mill die al in de negentiende eeuw onderscheidde tussen twee manieren om te vergelijken, 'the Method of Difference' en 'the Method of Agreement',

14 Frits de Jong Edz, 'Verzuiling in historisch perspectief', Socialisme en Democratie (1957) 2-10; Arend Lijphart, Verzuiling, pacificatie en kentering in de Nederlandse politiek (1968; Amsterdam 1976) 82-84, 189 en passim.

15 Siep Stuurman, Verzuiling, kapitalisme en patriarchaat (1983; Nijmegen 1984) 11, 61 en passim.

16 Karel Davids, Jan Lucassen en Jan Luiten van Zanden, De Nederlandse geschiedenis als afwijking van het algemeen menselijk patroon (Amsterdam 1988); de uitdrukking Algemeen Menselijk Patroon is zoals bekend van Jan Romein.

17 Karel Davids en Jan Lucassen (eds.), A Miracle Mirrored. The Dutch Republic in European Perspective (Cambridge 1995). 
wat tegenwoordig dan de individualiserende tegenover de generaliserende methode heet, of vaker de contrastvergelijking tegenover de parallelle vergelijking. ${ }^{18}$ In het eerste geval zoekt men bij vergelijking naar verschillen, in het laatste naar overeenkomsten. In de jaren tachtig voerde Hans Righart een parallelle vergelijking uit tussen Nederland en een aantal andere kleine landen met katholieke verzuiling. Dat relativeerde dus deels het unieke karakter van het verschijnsel, maar ook hij opende zijn boek met de verzekering 'dat de verzuiling een raster is geweest waarlangs de vaderlandse geschiedenis zich ruwweg de laatste honderd jaar bewogen heeft'; niet bepaald een relativering van het vaderlandse karakter van de verzuiling. ${ }^{19}$

Voor zover de overige auteurs expliciet vergeleken, ging het meestal om de contrastvergelijking (die bij historici in het algemeen het meest populair is ${ }^{20}$ ). Dit gold ook voor politicologen zoals Stuurman die het contrast met andere landen en dus het specifiek Nederlandse benadrukte, en eerder al Lijphart en Daalder. Zo sterkten politicologen historici in de gedachte dat het hier om iets echt Nederlands ging. Vergelijkingsspecialisten als de Duitse historici HeinzGerhard Haupt en Jürgen Kocka menen dat de analytische vergelijkende geschiedschrijving verbonden is met theoretische verdieping en het is zonder meer duidelijk dat op die manier veel uitstekende geschiedschrijving tot stand is gekomen. ${ }^{21}$ Het levert op zichzelf echter geen uitweg uit de kwestie van de navelstaarderij. Die uitweg ontstaat zelfs niet door het vermijden van de gebreken die aan de contrastvergelijking worden verweten, zoals onkritisch 'descriptief holisme' dat het zoeken naar verklaringen in de weg zou staan. ${ }^{22}$ Expliciete vergelijking makkt wel een discussie mogelijk over alle vormen van exceptionalisme die voor de diverse nationale politieke geschiedenissen zo vaak zijn geclaimd. De claim van exceptionalisme veronderstelt vergelijking, maar die wordt zelden systematisch uitgevoerd door de verkondigers ervan.

In de praktijk hebben politiek historici vaak een op empirie gerichte houding aangenomen. Met theorie schieten we niet veel op, meenden ze, want historici zijn geïnteresseerd in concrete historische verschijnselen. Interna-

18 Samenvattend in kort bestek Stefan Berger, 'Comparative History', in: idem, Heiko Feldner en Kevin Passmore (eds.), Writing History. Theory E Practice (Londen 2003) 161-179; zie ook in het kader van verzuiling het boek van Righart in de volgende noot. Meer categorieën onderscheidt bijvoorbeeld A. van den Braembussche, 'Historical Explanation and Comparative Method. Towards a Theory of the History of Society', History and Theory 28 (1989) 2-24, in een bespreking van vergelijkende literatuur en theorie.

19 Hans Righart, De katholieke zuil in Europa. Een vergelijkend onderzoek naar het ontstaan van verzuiling onder katholieken in Oostenrijk, Zwitserland, Belgie en Nederland (Meppel 1986) 9.

20 Opmerkingen daarover bijvoorbeeld in Heinz-Gerhardt Haupt en Jürgen Kocka (eds.), Geschichte und Vergleich. Ansätze und Ergebnisse international vergleichender Geschichtsschreibung (1996) 24, en het hierna te noemen artikel van Skocpol en Somers, 192.

21 Haupt en Kocka, Geschichte und Vergleich. Zie ook Heinz-Gerhard Haupt, 'Comparative History. A Contested Method', Historisk Tidskrift 127 (2007) 697-214.

22 Theda Skocpol en Margaret Somers, 'The Uses of Comparative History for Macrosocial Inquiry', Comparative Studies in Society and History 22 (1980) 174-197; aldaar 193. 
tionale vergelijking kon, in de woorden van Hans Blom uit 1985, bij het historisch onderzoek naar verzuiling hooguit van belang zijn als 'de concrete historische context van de betrokken landen' niet uit het oog werd verloren. Of de verzuiling behoorde tot de 'uniek Nederlandse verschijnselen' was voor het onderzoek ernaar ook niet van groot belang. ${ }^{23}$ Dat zei Blom in de jaren tachtig. In 2000 was hij veel sceptischer geworden over de waarde van het begrip verzuiling als uitgangspunt voor onderzoek; internationaal vergelijkend onderzoek was nu in zijn ogen interessant geworden om vast te stellen of, en zo ja hoe, verzuiling zich eigenlijk onderscheidde van de internationale processen waarvan het in feite een variant was. ${ }^{24}$ Onderzoek naar lokale vormen van verzuiling bleek vooral te leiden tot nader onderzoek naar vormen van religie, sociale verhoudingen en politiek in de negentiende eeuw in het algemeen. Vandaaruit kwam de vraag centraal te staan in hoeverre Nederland eigenlijk uniek was. Liet het land wel meer zien dan een eigen versie van verschijnselen die in feite internationaal van aard waren? Zo veranderde geleidelijk de vraagstelling van het specifiek Nederlandse naar meer algemene vragen. Voor die vragen geeft de literatuur over verzuiling voldoende aanknopingspunten. Daarom hierna twee voorbeelden van wegen waarlangs onderzoek naar wat geldt als het terrein van de verzuiling aan een minder exclusief Nederlandse politieke geschiedenis kan bijdragen.

\section{Parallelle vergelijking en buitenlandse voorbeeldwerking ${ }^{25}$}

Ten eerste kan men de verzuiling opvatten als een begeleidend verschijnsel of uiting van wat wel partijendemocratie wordt genoemd. Dit was een in veel landen voorkomende vorm van politiek die werd gedomineerd door ideologisch gemotiveerde massapartijen waaraan de kiezers hun leven lang loyaal waren en die aan het einde van de negentiende eeuw opkwam en in Nederland bloeide tot in de jaren zestig. Zoals vaak is opgemerkt was de keuze voor een partij in de partijendemocratie over het algemeen niet een kwestie die per verkiezing bepaald werd en zomaar kon veranderen maar een zaak van de (permanente) identiteit van de kiezer. Men kan hierbij denken aan de

23 J.C.H. Blom, 'Onderzoek naar verzuiling in Nederland. Status quaestionis en wenselijke ontwikkeling', in: idem en C.J. Misset (eds.), 'Broeders sluit u aan'. Aspecten van verzuiling in zeven Hollandse gemeenten (Amsterdam 1985) 18.

24 Hans Blom, 'Vernietigende kracht en nieuwe vergezichten', in: J.C.H. Blom en J. Talsma (eds.), De verzuiling voorbij. Godsdienst, stand en natie in de lange negentiende eeuw (Amsterdam 2000) 232.

25 Samenvattingen van de internationale, maar vaak vanuit Duitsland geïnitieerde discussie bij onder anderen Jürgen Kocka, 'Comparison and Beyond', History and Theory 42 (2003) 39-44; Hartmut Kaelble, 'Die interdisziplinären Debatten über Vergleich und Transfer', in: idem en Jürgen Schriewer (eds.), Vergleich und Transfer. Komparistik in den Sozial-, Geschichts- und Kulturwissenschaften (Frankfurt en New York 2003) 469-493; Budde, Conrad en Janz, Transnationale Geschichte. Zie voor Nederland recentelijk De Negentiende Eeww 32:1 (2008), over 'reizende ideeën'. Vergelijk Henk te Velde, 'Political Transfer. An Introduction', European Review of History 12 (2005) 205-221. 
Nederlandse confessionelen en sociaal-democraten, die vaak hun leven lang trouw bleven aan hun partij en wier partijkeuze vervlochten was met alles wat zij deden van kerkelijke betrokkenheid en lidmaatschap van verenigingen tot hun gehele sociale leven. ${ }^{26}$ Verandering van partij zou hier bijna verandering van identiteit zijn geweest.

AJC-optocht op de 1 mei-viering van 1931 georganiseerd door de SDAP in het Olympisch stadion in Amsterdam. Typisch Nederlands? Vergelijkbare bijeenkomsten vonden niet alleen plaats in het verzuilde Nederland - bij vooral de katholieken - maar ook bij zusterpartijen in bet buitenland. Bron: Collectie Internationaal Instituut voor Sociale Geschiedenis, Amsterdam.

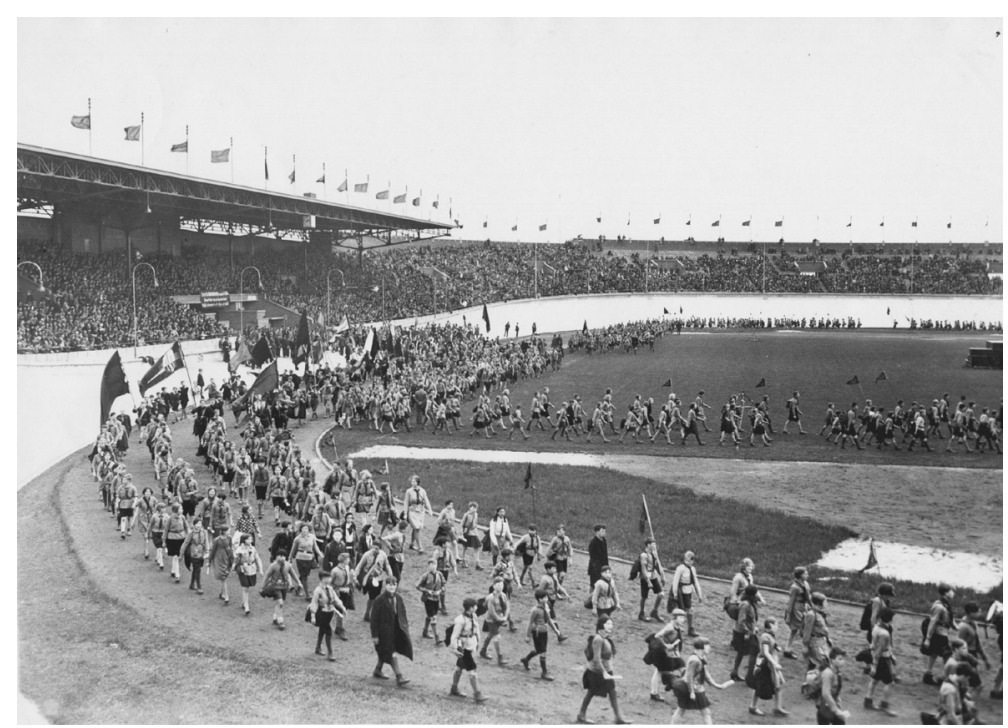

De klassieke analyse van het type partij dat hiermee verbonden is, is Robert Michels over de Duitse sociaal-democratie. ${ }^{27}$ De Duitse sociaal-democratische partij is dan ook vaak beschouwd als het model van de partijendemocratie, maar eenzelfde analyse zou van de Nederlandse verzuilde partijen gemaakt kunnen worden. Historici hebben in hun analyse van de Nederlandse verzuiling de politieke partij als zodanig nooit centraal gesteld - politicologen letten daar wel meer op - en zagen het eigene van de verzuiling juist daarin dat die alle aspecten van het leven doordrong. Deze doordringing was echter ook elders het begeleidende effect van de partijendemocratie op haar hoogtepunt, zeker in het geval van de Duitse sociaal-democratie die Michels analyseerde en die een 'Milieupartei' was, het Duitse equivalent van wat in Nederland verzuild heet. Nederlandse historici hebben zich vooral geconcentreerd op de sociale

26 Zie bijvoorbeeld de beschouwing over 'Party Democracy' in Bernard Manin, The Principles of Representative Government (Cambridge 1997) 206-218.

27 Robert Michels, Zur Soziologie des Parteiwesens in der modernen Demokratie. Untersuchungen über die oligarchischen Tendenzen des Gruppenlebens (1911; Stuttgart 1989). 
aspecten van verzuiling. Dat lag ook voor de hand gezien het traditionele gebrek aan belangstelling in Nederland voor het politieke leven in engere zin: zelfs voor de aanhang van de twee meest 'politieke' politieke partijen ${ }^{28}$, de SDAP en de ARP ('politiek' in de zin dat zij een zekere passie ontwikkelden voor het politiek debat en voor de ontwikkeling van het formele politieke circuit), was de wereld buiten de institutionele politiek, de wereld van levensen wereldbeschouwing, belangrijker. Politiek werd in Nederland snel gereduceerd tot bestuur. Zelfs onder sociaal-democraten stonden op den duur bestuurders als Wibaut en Drees het hoogste in aanzien en in het algemeen stonden volksvertegenwoordigers mede in aanzien doordat ze deel uitmaakten van de wereld van notabelenbestuurders.

Juist de relativering van politiek in de enge betekenis van het woord door de nadruk op de verzuiling als sociaal verschijnsel past goed in de partijendemocratie. Er is veel te zeggen voor de redenering dat de Nederlandse verzuiling een van de meest wezenlijke kenmerken van de partijendemocratie in optima forma demonstreerde: het verdwijnen of tenminste sterk verwateren van de grenzen tussen organisaties in het sociale en het politieke domein en de wederzijdse doordringing van staat en maatschappij, in de woorden van Jan Romein. In deze wereld werd partijkeuze beleefd als onderdeel van de sociale en persoonlijke identiteit. Voor de gewone burger betekende deelname aan verzuilde organisaties niet allereerst een politieke daad in de strikte betekenis van het woord, maar wel een sociaal en moreel kleur bekennen en een deelname aan een morele gemeenschap. Zo illustreert de Nederlandse casus een belangrijk kenmerk van de partijendemocratie, niet doordat die casus zo eigenaardig afwijkt van het algemeen menselijk patroon, maar doordat hij aspecten van de ontwikkeling van politiek in een bepaalde fase zo pregnant kan duidelijk maken. Er zijn weinig landen die zo goed in Bernard Manins typering van de partijendemocratie passen als Nederland. Zo leent Nederland zich heel goed om de aard van die vorm van democratie te onderzoeken. Wel moet men zich dan realiseren dat andere aspecten van de partijendemocratie wellicht weer beter onderzocht kunnen worden aan de hand van andere landen. ${ }^{29}$

Wat denigrerend schrijft de politicoloog Almond in zijn hiervoor geciteerde artikel uit 1956 dat in de politieke partijen in deze fase:

political affiliation is more of an act of faith than of agency. [...] The political actors come to the market not to exchange, compromise, and adapt, but to preach, exhort, convert, and transform the political system into something other than a bargaining agency.

28 Piet de Rooy, 'De sociaal-democratische passie voor politiek', in: Jos de Beus e.a., De ideologische driehoek. Nederlandse politiek in historisch perspectief (Amsterdam en Meppel 1996) 136, beperkt zich tot de sociaal-democratie, maar de ARP zou er met enig recht aan kunnen worden toegevoegd.

29 Bijvoorbeeld Pierre Rosanvallon, Le peuple introuvable. Histoire de la représentation démocratique en France (Parijs 1998) 171-217, geeft een beknopte analyse van een aantal aspecten van de 'démocratie des partis'. 
Vooral de woorden in dit citaat die naar religie en geloof verwijzen, waren uitermate verdacht zo kort na de Tweede Wereldoorlog die de uitwassen van politieke religies had getoond. ${ }^{30}$ De verzuilde partijen bezaten inderdaad de quasi-religieuze trekken die Almond signaleerde, maar ze waren tegelijk democratisch. Dit type partij kwam in veel landen voor, waaronder Duitsland, maar juist de Nederlandse variant kan veel vertellen over de aard van deze partijen. Onderzoek zou gebruik kunnen maken van de eigenaardige trekken van de Nederlandse partijen om de aard van een internationaal veel voorkomend type partij waarvoor vaak de Duitse sociaal-democratie als prototype wordt beschouwd, te kunnen tonen. ${ }^{31}$ Zo wordt het eigene van de Nederlandse situatie juist gebruikt om algemeen voorkomende internationale verschijnselen in de meest uitgesproken vorm te analyseren. Hier dient vergelijking dus niet om het bijzondere van Nederland als zodanig te belichten, maar om via parallelle vergelijking bepaalde internationale vormen van politiek te bestuderen. In dit nummer van de $B M G N$ verkent Niek Pas in wat algemenere zin de weg van de parallelle vergelijking voor de Nederlandse jaren zestig, die ondanks hun evidente internationale inbedding toch ook vaak vrijwel exclusief nationaal geïnterpreteerd worden.

Ten tweede zou ook meer nadruk kunnen worden gelegd op de internationale netwerken waarin de Nederlandse verzuilde groepen vervlochten waren. De Nederlandse SDAP was niet tot ontwikkeling gekomen zonder Duitse financiering en Duitse voorbeeldwerking ${ }^{32}$ en de Nederlandse katholieke partij is ook gevormd naar Duits voorbeeld. Dit is allemaal niet onbekend, maar het staat zelden centraal in de aandacht. Hans Blom wijst er in zijn terugblik op het Amsterdamse verzuilingsproject op dat historici graag de 'ontstaansgeschiedenis' van bepaalde verhoudingen bestuderen in de overtuiging dat die inzicht zal opleveren in de aard ervan. ${ }^{33}$ Vanaf de romantiek hebben veel historici zelfs gedacht dat de identiteit van een verschijnsel in zijn historische wortels te vinden is. Lange tijd zijn zij echter in hun onderzoek vrijwel uitsluitend op zoek gegaan naar nationale achtergronden van nationale verschijnselen. Daar is op zich niets op tegen, maar als de analyse zich daartoe beperkt, wordt het een en ander over het hoofd gezien. Het zou dus aanbeveling verdienen op zoek te gaan naar buitenlandse wortels van juist verschijnselen zoals verzuiling, die zo vaak als typisch vaderlands zijn getypeerd. Niet om nu te gaan betogen dat het allemaal import is, maar om te

30 Over met name fascistische politieke religies onder meer Emilio Gentile, Politics as Religion (Princeton 2006).

31 Met andere accenten maar uitgebreider in Henk te Velde, 'Het wij-gevoel van een morele gemeenschap. Een politiek-culturele benadering van partijgeschiedenis', Jaarboek DNPP 2004 (2006) 106-123.

32 Bijvoorbeeld Bert Altena, 'Bürger in der Sozialdemokratie. Ihre Bedeutung für die Entwicklung der Sozialdemokratischen Arbeiterpartei (SDAP) in den Niederlanden 1894-1914', Geschichte und Gesellschaft 20 (1994) 533-548. In Leiden voert Adriaan van Veldhuizen een promotie-onderzoek uit naar de partijcultuur van de vroege SDAP en de betekenis daarvoor van de relatie met de Duitse sociaal-democratie.

33 Blom, 'Vernietigende kracht', 212. 
laten zien dat dit soort zaken zich niet in een internationaal isolement ontwikkelde en om de internationale vervlechting te tonen.

$\mathrm{Zo}_{\mathrm{o}}$ is duidelijk dat Herman Schaepman in de negentiende eeuw de katholieken politiek wilde organiseren in concurrentie met Nederlandse liberalen en antirevolutionairen, maar zijn inspiratie deed hij op in Duitsland. Het is opvallend dat de Duitse invloed in een boek als dat van Stuurman alleen verschijnt bij een verschijnsel als de interconfessionele vakbond, dat op niets is uitgelopen. Schaepmans hele werk is echter niet te begrijpen zonder het grote voorbeeld van het Zentrum, de Duitse katholieke partij, en zijn leider Ludwig Windthorst: 'Duitschland geeft het voorbeeld', schreef Schaepman in 1877, en dat was voor hemzelf heel duidelijk waar. ${ }^{34}$ Dat Schaepman in $1883 \mathrm{kwam}$ met een 'proeve van een program' voor een katholieke partij, kan gelezen worden als antwoord op Kuypers programma, maar de inspiratie kwam uit Duitsland. Zelfs de titel lijkt een directe echo van het tien jaar eerder verschenen 'Entwurf zu einem politischen Programm' van de Duitse bisschop en politicus Von Ketteler. ${ }^{35}$

\section{Conclusie}

Zouden we meer dan tot dusver gebeurt de internationale vervlechting van nationale politieke verschijnselen nagaan, dan verliest de nationale politieke geschiedenis nog wat meer van zijn vanzelfsprekendheid. Ondertussen kunnen historici in feite hun gebruikelijke methodes gewoon blijven toepassen. In hun genealogie van historische verschijnselen zouden ze alleen meer aandacht aan internationale wortels moeten besteden. Voorbeelden en mogelijke uitwerkingen daarvan bieden in dit nummer de bijdragen van Annie Jourdan en deels Mieke Aerts en Remieg Aerts. Dergelijk onderzoek zal in ieder geval voor de negentiende en twintigste eeuw niet tot de conclusie leiden dat het nationale kader onbelangrijk is, maar het zal de betekenis daarvan wel beter kunnen vaststellen.

Het zou kunnen dat de discussie daarbij in eerste instantie beperkt blijft tot wat historici zeggen dat ze doen in plaats van wat ze feitelijk doen. ${ }^{36}$ Maar ook dat heeft zijn nut, omdat zo het bewustzijn voor oudere blinde vlekken en de aandacht voor de internationale context in de politieke geschiedenis gestimuleerd wordt. Voor een reeks single-issue-bewegingen heeft Maartje Janse laten zien hoe groot de internationale, vooral Britse inspiratie in de negentiende eeuw was. ${ }^{37}$ Telkens werd daarbij aan Nederlandse kant benadrukt dat de inspiratiebron wel moest worden aangepast aan de Nederlandse situatie.

34 H.J.A.M. Schaepman, 'Het Duitsche Centrum', in: idem, Menschen en boeken. Verspreide opstellen II (Utrecht 1894) 164.

35 Wilhelm Emmanuel von Ketteler, Die Katholiken im deutschen Reiche. Entwurf zu einem politischen Programm (Mainz 1873); vergelijk onder meer Jos van Wely, Schaepman. Levensverhaal (Antwerpen 1952) 207; zie ook Pieter de Coninck, Een les uit Pruisen. Nederland en de Kulturkampf, 1870-1880 (Hilversum 2005).

36 Zoals Sheehan, 'Sonderweg revisited', opmerkt over het soms wel erg op het programmatische aspect geconcentreerde Duitse historiografische debat. 
De discussie die daarover werd gevoerd, was in feite een doorgaande poging tot omschrijving van wat nu echt Nederlands was. Dat werd gedefinieerd in een gesprek met het buitenland. Zo bevestigde in een andere context een Belgisch vergelijkend onderzoek naar parlementen uit de jaren 1880 het Nederlandse zelfbeeld van een rustige parlementaire stijl dat sindsdien gekoesterd is; voor dat Belgische boek hadden dan weer Nederlandse Kamerleden materiaal aangeleverd. ${ }^{38}$ Op die manier betekent onderzoek naar buitenlandse inspiratie ook onderzoek naar de voortdurende constructie en reconstructie van de Nederlandse identiteit, die in de negentiende eeuw nog meer een project in uitvoering of een programma was dan in de twintigste, toen ze door de organisaties van de verzorgingsstaat als vanzelfsprekend uitgangspunt werd genomen. Hoe dan ook was er altijd de relatie met het buitenland.

In ieder geval in de politieke geschiedenis van de laatste eeuwen veronderstellen en bepalen nationale en internationale geschiedenis elkaar, zoals Mieke Aerts in haar bijdrage over de vrouwenbeweging ook laat zien. Het is daarbij niet gemakkelijk uit te maken wanneer het buitenland slechts als retorisch argument wordt ingeroepen om iets af te wijzen of aan te prijzen en wanneer het om een daadwerkelijke overname of zelfs maar invloed gaat. Het onderscheid heeft ook iets kunstmatigs. 'Nationaal' was lange tijd immers een hoera-woord en 'onnationaal' een scheldwoord, zelden waren het neutrale begrippen. Wie ze gebruikte had een doel, 'deed' dan vaak veel meer dan alleen beschrijven. Ook retorisch gebruik van de begrippen zonder 'echte' overname had op zichzelf al effecten. Overdenking van die effecten maakt de geschiedenis van politiek rijker en spannender, breidt als het ware de mogelijkheden van het genre uit.

Helemaal onbekommerd schrijven Nederlandse historici al lang niet meer over hun nationale geschiedenis. Niemand onder hen zou tegenwoordig graag van nationale bekrompenheid beschuldigd willen worden. Dat probleem kennen buitenlandse auteurs die zich bezighouden met de Nederlandse geschiedenis veel minder en het is geen toeval dat er onder hen zijn die de clichés over die geschiedenis niet zozeer willen ontmantelen als wel juist als uitgangspunt nemen voor hun werk. Schama heeft weinig moeite om te schrijven over een eeuwenlange Nederlandse neiging om stoepjes te schrobben en overbrugt als toegift van zijn studie over de zeventiende eeuw ook gemakkelijk de afstand tussen die eeuw en het hedendaagse Lelystad of Almere. Het paste in zijn controversiële maar ook stimulerende cultuuranalyse. De uit Tsjechoslowakije afkomstige socioloog Ernest Zahn was vooral in het contemporaine Nederland van de jaren zeventig geïnteresseerd, maar zag daar

37 Maartje Janse, De afschaffers. Publieke opinie, organisatie en politiek in Nederland 1840-1880 (Amsterdam 2007).

38 Wilbert van Vree, Nederland als vergaderland. Opkomst en verbreiding van een vergaderregime (Groningen 1994) 224; Jouke Turpijn, Mannen van gezag, De uitvinding van de Tweede Kamer 1848-1888 (Amsterdam 2008) 186-187; Henk te Velde, 'Het feest van de democratie in Nederland. De traditie van parlementaire vertegenwoordiging', Jaarboek Parlementaire Geschiedenis 2008 (Amsterdam 2008) 16 en passim. 
voortdurend de zeventiende eeuw doorheen schemeren. Zelfs de voorzichtige en precieze, uit Amerika afkomstige historicus James Kennedy hanteert sweeping statements als de 'niet moeilijk' te 'constateren' 'doorgaande lijn van verdraagzaamheid' in de Nederlandse geschiedenis. Het staat een goede geschiedschrijving over zijn eigenlijke onderwerp niet in de weg - zijn werk is daarover zelfs het meest geciteerde werk - , maar het leidt wel tot een sterke benadrukking van nationale oorzaken van nationale verschijnselen zonder veel aandacht voor alternatieven. ${ }^{39}$

Internationalisering van de nationale geschiedenis is vanzelfsprekend geen panacee voor de gebreken van de politieke geschiedenis, laat staan voor die van de geschiedwetenschap in het algemeen. Zij kent bovendien op haar beurt weer haar blinde vlekken en modieuze verschijnselen. De discussie erover geeft echter wel stof voor een nieuwe balans van de vaderlandse geschiedenis in hedendaags perspectief.

Henk te Velde (1959) is hoogleraar Vaderlandse Geschiedenis in Leiden. Hij publiceert op het terrein van de Nederlandse en West-Europese politiek en politieke cultuuur in de negentiende en twintigste eeuw. In 2010 publiceert hij Van regentenmentaliteit tot populisme. Politieke tradities in Nederland en (co-)redigeert hij een boek over de geschiedenis van het Binnenhof en één over Robert Fruin en de vaderlandse geschiedenis.

39 Simon Schama, Overvloed en onbehagen. De Nederlandse cultuur in de Gouden Eeuw (Amsterdam 1988) inleiding en epiloog; Ernest Zahn, Regenten, rebellen en reformatoren. Een visie op Nederland en de Nederlanders (Amsterdam 1991); James Kennedy, Nieuw Babylon in aanbouw. Nederland in de jaren zestig (Amsterdam en Meppel 1995) 209 - zie over dit laatste boek ook Niek Pas, 'De problematische internationalisering van de Nederlandse jaren zestig', Bijdragen en Mededelingen betreffende de Geschiedenis der Nederlanden (BMGN) 124:4 (2009) 618-630. 


\title{
Internationalisering en de Nederlandse Opstand
}

\author{
Judith Pollmann
}

\begin{abstract}
Internationalising The Dutch Revolt
At around 1960 the interpretations of the Dutch Revolt that were propounded in 'grand narratives' of sixteenth-century Europe, differed considerably from those on offer in the 'national' historiography of the Revolt. That this was to change drastically over the following five decades, was only partly due to changes in Dutch historiography. Most impulses to 'internationalise' interpretations of the Dutch Revolt came from outside the Low Countries. While Geoffrey Parker situated the Revolt in its Habsburg context, research into Netherlandish Protestantism also emphasised its international dimensions. Many political developments within the Low Countries, too, can best be understood in a European context. This article offers an analysis of this development, and explores what this might mean for our prospects for a new synthetic study of the Revolt of the Netherlands.
\end{abstract}

Wie spreekt over de internationalisering van de nationale geschiedenis kan daar tenminste drie dingen mee bedoelen. In de eerste plaats is er het gegeven dat de 'nationale' geschiedenis in toenemende mate het product is van internationaal onderzoek. Vervolgens is er de constatering dat de nationale geschiedenis in internationale context moet worden geduid. Tenslotte, en dat is de gedachte achter dit nummer van de $B M G N$, is veel in de nationale geschiedenis niet zo nationaal als wij vaak geneigd zijn te denken. In alle drie de betekenissen van de term is de geschiedenis van de Nederlandse Opstand een schoolvoorbeeld van de 'internationalisering' van de nationale geschiedenis. Zoals ik hier hoop te laten zien kunnen een aantal van de belangrijkste nieuwe inzichten uit het onderzoek naar de Opstand van de laatste decennia direct worden gekoppeld aan de internationalisering van het perspectief op de 'troebelen' in de Nederlanden in de zestiende en zeventiende eeuw.

Die internationalisering is echter zeker niet uitsluitend iets van de laatste tijd. De Opstand was een bij uitstek 'internationale' oorlog, die enorme Europese repercussies had, en die ook al door tijdgenoten internationaal geduid werd. Veel van de eerste geschiedschrijvers van de Opstand waren geen Nederlanders. Niet alleen Spaanse kronieken vonden snel de weg naar de drukpers, in de zeventiende eeuw hadden ook Italianen als Famiano Strada en Guido Bentivoglio een grote impact op de geschiedschrijving van de Nederlandse oorlogen. ${ }^{1}$ In de achttiende en negentiende eeuw werd de Opstand

1 De Spaanse historiografie wordt besproken in Yolanda Rodríguez Pérez, De Tachtigjarige oorlog in Spaanse ogen. De Nederlanden in Spaanse historische en literaire teksten (circa 15481673) (Nijmegen 2003); Famiano Strada, De bello belgico decas prima ab excessu Caroli V. imp. Usque ad initia praefecturae Alexandri Farnesii Parmae, ac Placentiae Ducis III (Rome 